\title{
EFEKTIVITAS KETERAMPILAN KOMUNIKASI KONSELOR TERHADAP KETERBUKAAN DIRI SISWA DI SMA NEGERI 3 PAREPARE
}

\author{
Iskandar, Aswar Anas, Zulfah \\ Institut Agama Islam Negeri (IAIN) Parepare \\ Email: Aswar@gmail.com
}

\begin{abstract}
This study examines the effectiveness of counselor communication on the self-disclosure of students in SMA Negeri 3 Parepare. Counselors in high schools get a clear role and position or place, where counselors as a component of student support services (student support services) to help the development of personal, social, career, and academic aspects of students through guidance and counseling programs to students in plan (individual student planning), responsive service delivery and system development (system support). Therefore, counselors are highly required to have effective communication skills to support counseling, so counseling communication skills can make students open themselves.

This type of research is descriptive qualitative using observation, interview, and documentation methods. The subject in this study was the BK teacher of SMA Negeri 3 Parepare as the school counselor using data analysis techniques namely interpretation data analysis techniques and triangulation analysis techniques.

The results of this study indicate that the stages of counseling can be seen based on the stages of effective communication conducted by counselors, including; 1) Fact finding, 2) Planning, 3) Communicating, 4) Evaluating. The communication skills applied by counselors in the implementation of counseling are (attending), empathy, summarizing, asking, and honesty. By using the communication model, in this study found that the counselor's communication achieved students' self-disclosure as evidenced by giving their trust to the counselor, expressing honest statements in the counseling process, and students feeling relieved after the counseling. Based on some of the results obtained by researchers, the communication skills conducted by counselors to achieve students' self-disclosure are effective.
\end{abstract}

Keywords: Counselor Communication Skills, Student Openness

\section{PENDAHULUAN}

Konselor mesti memiliki keterampilan komunikasi, proses konseling tidak mungkin dapat berjalan ataupun terjadi tanpa adanya komunikasi. Komunikasi merupakan landasan bagi berlangsungnya suatu konseling. Konseling pada dasarnya melibatkan komunikasi antara dua pihak yaitu konselor dan konseli yang 
berlangsung dalam situasi konseling. Keberhasilan konseling sangat ditentukan oleh keefektifan komunikasi diantara partisipan konseling yaitu konselor, konseli dan pihak lain yang terkait. Hal ini secara jelas dinyatakan dalam (Q.S.AnNisa:3/63).

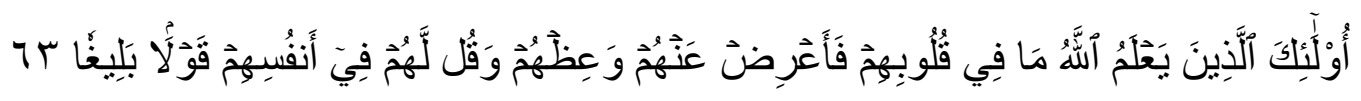

Terjemahnya:

Mereka itu adalah orang-orang yang Allah mengetahui apa yang di dalam hati mereka. Karena itu berpalinglah kamu dari mereka, dan berilah mereka pelajaran, dan katakanlah kepada mereka perkataan yang berbekas pada jiwa mereka $^{1}$

Ayat di atas menggambarkan bahwa dalam proses konseling, seorang konselor mesti memiliki keterampilan berkomunikasi dalam menghadapi konseli agar dapat memberikan pelajaran dan perkataan yang berbekas kepada konseli. Konselor tentunya diharuskan agar mampu memahami konseli, hal ini dilakukan agar mampu mencapai tujuan dari proses konseling. Oleh karena itu, sentuhan yang harus dilakukan konselor kiranya mampu menarik kepercayaan konseli agar dapat menunjang proses konseling yang berkelanjutan.

Hubungan yang dibangun ini konselor dituntut untuk mampu berkomunikasi secara efektif agar menunjang pelaksanaan konseling. Salah satu keterampilan yang diperlukan oleh konselor adalah keterampilan berkomunikasi secara dialogis khususnya konseli. Dengan cara ini, maka semua usaha dapat dilaksanakan dengan efektif dan efisien mungkin. Komunikasi konseling pada dasarnya merupakan salah satu bentuk komunikasi interaktif antara satu pihak dengan pihak lain melalui penciptaan suatu situasi dalam upaya untuk memperoleh informasi yang diperlukan dalam pembuatan keputusan secara tepat. Komunikasi dialogis merupakan bentuk komunikasi dua arah antara dua orng individu atau lebih dalam membahas suatu masalah tertentu dengan tujuan tertentu. $^{2}$

\footnotetext{
${ }^{1}$ Departemen Agama RI, Al Quran dan Terjemahnya, Cet. X; (CV Diponegoro : Yayasan Penyelenggara Penterjemah Al Quran, 2010), h. 136.

${ }^{2}$ Juntika N, Landasan dan Konseling (Bandung: PT Remaja Rosdakarya, 2005), h.
} 
Keberhasilan proses konseling sangat ditentukan oleh komunikasi di antara partisipan konseling, sehingga dapat dikatakan bahwa komunikasi merupakan landasan bagi berlangsungnya suatu konseling, oleh karena itu konseling merupakan proses pemecahan masalah psikologis konseli melalui wawancara antar pribadi, antar konseli dan konselor dalam suasana dialog. Maka keterampilan komunikasi konseling merupakan sesuatu yang penting untuk dimiliki konselor.

Kemampuan berkomunikasi yang demikian dapat dijadikan sebagai alat oleh konselor untuk:

1. Membuka dan mengawali proses konseling

2. Mengumpulkan, merangkum, dan membantu mencari solusi atas persoalan yang dihadapi konseli

3. Menunjukan respon positif agar konseli merasa nyaman, serta merasa diterima dengan baik

4. Membangun rasa percaya diri konseli dalam mengulangi masalah

5. Mengembangkan perilaku lebih efektif. ${ }^{3}$

Keterampilan komunikasi dari seorang konselor dapat membuat keterbukaan diri konseli. Pada kehidupan manusia, keterbukaan diri merupakan alat terpenting untuk kelangsungan hidupnya. Tanpa adanya keterbukaan diri maka manusia akan mengalami hambatan dalam berkomunikasi. Dengan keterbukaan diri, keakraban seorang individu dengan individu lainnya dapat semakin erat. Untuk dapat memberikan gambaran yang jelas mengenai keterbukaan diri. Keterbukaan diri adalah mengungkapkan reaksi atau tanggapan kita terhadap situasi yang sedang kita hadapi serta memberikan informasi tentang masa lalu yang relevan atau yang berguna untuk memahami tanggapan kita dimasa kini. Keterbukaan diri ialah jenis komunikasi dimana kita mengungkapkan informasi tentang diri kita sendiri yang biasanya kita sembunyikan.

Kedalaman sikap terbuka tergantung pada situasi dan orang yang diajak untuk berinteraksi. Situasi yang menyenangkan dan perasaan aman dapat 
membangkitkan seorang untuk lebih membuka diri. Selain itu adanya rasa percaya dan timbal balik dari lawan bicara menjadikan seseorang cenderung memberikan reaksi yang sepadan. Manusia mempunyai naluri untuk berkelompok atau berkawan dengan manusia lain. Dalam kelompok tersebut manusia dituntut dapat berkomunikasi dengan orang lain agar tidak terisolasi dari pergaulan dilingkungannya. Dalam berkomunikasi pada dasarnya individu tidak bisa langsung mengungkapkan apa yang akan diungkapkan. Untuk bisa mengungkapkan masalah atau informasi, hubungan antar individu haruslah akrab dan terbuka.

\section{PEMBAHASAN}

Model Komunikasi Efektif Konselor terhadap Keterbukaan Diri Siswa di SMA Negeri 3 Parepare

Pelaksanaan konseling tidak mungkin dapat berjalan ataupun terjadi tanpa adanya komunikasi, karena komunikasi merupakan landasan bagi berlangsungnya suatu konseling. Konseling pada dasarnya melibatkan komunikasi antara dua pihak yaitu konselor dan siswa selaku konseli yang berlangsung dalam situasi konseling di SMA Negeri 3 Parepare, keberhasilan konseling sangat ditentukan oleh keefektifan komunikasi diantara partisipan konseling yaitu konselor, siswa dan pihak lain yang terkait.

Keterampilan komunikasi konselor menjadi salah satu aspek yang diprediksi berpengaruh terhadap keberhasilan konseling. Keterampilan komunikasi konselor adalah seperangkat kecakapan khusus untuk mengirim dan menerima pesan yang dimiliki oleh konselor untuk membantu konseli dalam proses konseling menemukan alternatif pilihan secara tepat dalam menghadapi permasalahan yang dialami.

Oleh karena itu pada pembahasan ini peneliti akan mengurai tahapantahapan komunikasi efektif yang dilakukan oleh konselor di SMA Negeri 3 Parepare berdasarkan; tahap fact finding, tahap plaining, tahap communicating dan tahap evaluation. 


\section{Tahap Penemuan Fakta (fact finding)}

Tahap ini merupakan tahap dimana kegiatan lebih difokuskan untuk mengetahui apakah situasi dan pendapat yang terjadi dalam ruang lingkup siswa di sekolah terhadap suatu langkah yang akan diambil, maupun yang sedang dilaksanakan itu dapat menunjang atau justru malah akan menghambat kegiatan konseling yang akan dilakukan konselor.

Konseling yang dilakukan di SMA Negeri 3 Parepare pada dasarnya dilakukan oleh masing-masing guru Bimbingan dan Konseling yang kerap disapa dengan panggilan guru BK di sekolah. Konselor dalam melaksanakan konseling tentunya berdasar dari fakta yang terjadi di lingkungan sekolah. Hal yang perlu dinilai konselor adalah permasalahan siswa yang akan dihadapi oleh konselor nantinya. Sejalan dengan penjelasan yang terurai sebelumnya salah satu guru BK di SMA Negeri 3 Parepare yang menangani konseling pada kelas XI mengatakan bahwa:

Tugas kami tidak terlepas dari menilai situasi dan kondisi yang terjadi di sekolah. Tidak menutup kemungkinan, setiap harinya kita akan berhadapan dengan beberapa permasalahan-permasalahan yang lumrah terjadi dilingkungan sekolah. Dasar itulah yang digunakan dalam proses konseling tergantung dari kebutuhan dan masalah masing-masing siswa yang di alami dan juga tergantung dari kepribadian masing-masing siswa yang mengalami masalah.

Ketergantungan penerapan sistem komunikasi dalam konseling mengharuskan adanya permasalahan yang dimiliki siswa agar dijadikan sebagai dasar dalam pengambilan keputusan terkait pelaksanaan konseling yang akan lakukan oleh konselor. Sebelum membahas tentang model keterampilan komunikasi efektif yang kemudian menjadi penerapan guru BK di SMA Negeri 3 Parepare maka ada beberapa hal yang kemudian mengharuskan siswa diberikan konseling di sekolah.

\footnotetext{
${ }^{4}$ Andi baheriah, Guru BK SMA Negeri 3 Parepare, Wawancara oleh Penulis di Parepare, 16 Oktober 2017
} 


\section{Tahap perencanaan (planning)}

Tahap perencanaan atau planning merupakan bagian penting dalam usaha memperoleh penilaian yang menguntungkan. Perencanaan ini merupakan bidang yang cukup penting bagi pihak konselor, karena merupakan bagian yang menentukan bagi keberhasilan pelaksanaan konseling. Tugas konselor pada tahapan ini menghubungkan kegiatan komunikasi dengan kepentingan pelaksanaan konseling

Pada saat konselor telah mengidentifikasi permasalahan yang dimiliki konseli dalam hal ini siswa, maka ada beberapa hal selanjutnya yang dilakukan oleh guru BK selaku konselor. Mengenai hal tersebut Guru BK kelas XI di SMA Negeri 3 Parepare mengatakan bahwa:

Konseling tidak langsung dilakukan dan konselor pula ada beberapa keterampilan-keterampilan yang harus dimiliki. Karena itulah yang akan menunjang berjalannya pelaksanaan konseling yang kami lakukan nantinya.

Hasil wawancara di atas memberikan penjelasan bahwa konselor diharuskan memiliki keterampilan dalam melaksanakan konseling. Keterampilan yang dimiliki konselor akan membuat proses konseling dapat mencapai hasil yang lebih baik pula. Begitupun sebaliknya ketika perencanaan yang dilakukan tidak sesuai terhadap situasi dan kondisi dalam konseling yang dilakukan nantinya akan membuat keadaan semakin memburuk dalam pelakasanaannya.

Selain dari pada keterampilan, hal yang harus dilakukan konselor pada tahapan merencanakan dimana konselor diharuskan agar mengenal siswa secara kepribadian dan memahami permasalahan yang akan dihadapi nantinya.

\section{Tahap komunikasi (communicating)}

Tahap ini merupakan penyampaian informasi secara aktif kepada siswa dalam pelaksanaan konseling mengenai apa yang telah disusun dan juga

\footnotetext{
${ }^{5}$ Andi Baheria, Guru BK SMA Negeri 3 Parepare, Wawancara oleh Penulis di Parepare, 16 Oktober 2017
} 
diprogramkan oleh konselor. Pada proses penyampaian informasi kepada siswa, konselor menggunakan berbagai jenis, bentuk dan juga teknik komunikasi agar dapat mencapai efek tertentu seperti apa yang diharapkan.

Sapaan awal konselor dengan nada suara yang baik merupakan pintu pertama dari penghampiran, misalnya ucapan "Assalamu'alaikum", dan seterusnya. "Selamat pagi, selamat berjumpa, dan sebagainya." Hal itu dilakukan agar secara psikis situasi konseling memberikan suasana hubungan yang sedemikian rupa dimana konseli merasa dirinya diterima, merasa dekat, merasa penting dan dihargai martabatnya. Terkait keterampilan penghampiran atau attending ini, bapak Mahruf Asruri menjelaskan:

Memang harus dalam melakukan konseling kita memang diharuskan memulai dengan attending tadi. Sederhananya, bisa tidak kita secara pribadi kalau berbicara dengan orang untuk didengar tapi karena cara awal yang kita lakukan tidak tepat, contohnya; kita ucapkan kata yang tidak tepat dengan mungkin penekanan suara yang tegas. Pasti agak sulit untuk melanjutkan konseling ketahap selanjutnya. Maka dari itu, attending ini mengharuskan yang terjalin di awal bisa membuat konseling itu diterima oleh siswa.

Penghampiran atau attending dari beberapa penjelasan yang peneliti pahami dimana prosesnya memperhatikan beberapa hal, yakni; 1) ungkapan salam dan sapaan yang penuh sopan, dengan nada suara yang baik. 2) penampilan diri dengan postur (perawakan) fisik yang meyakinkan. 3) gerakan fisik yang disertai dengan perhatian secara menyeluruh. 4) pengakuan, sentuhan dan kontak fisik yang sederhana dan penuh perhatian, disertai dengan sikap yang menunjukkan bahwa kehadiran kita sebagai suatu yang akan memberikan makna bagi siswa yang berada pada pelaksanaan konseling. 5) memelihara kontak mata secara menyeluruh dan cepat sesuai dengan situasi dan topik bahasan. 6) mengamati dan menyimak dengan penuh perhatian.

\section{Tahap Evaluasi (evaluation)}

Setelah komunikasi dilaksanakan, maka konselor seharusnya mengetahui efek dari tahap komunikasi yang dilakukannya terhadap siswa yang telah

\footnotetext{
${ }^{6}$ Mahruf Asruri, Guru BK SMA Negeri 3 Parepare, Wawancara oleh Penulis di Parepare, 23 Oktober 2017
} 
mendapatkan konseling, maka haruslah dilakukan evaluasi. Evaluasi sendiri adalah tahap terakhir yang dilakukan konselor dari beberapa tahapan sebelumnya. Tujuan utama dari evaluasi di sini adalah untuk mengetahui apakah pelaksanaan konseling yang dilaksanakan sudah berjalan berdasarkan apa yang menjadi keinginan dan pencapaian dari konselor.

Tahapan konseling selanjutnya diharuskan adanya proses pemecahan masalah yang sifatnya berkelanjutan, dimana pemecahan masalah disini merupakan hal yang urgen. Konselor seharusnya memiliki keterampilan ini agar konseling dapat berjalan sesuai dengan apa yang diharapkan. Keterampilan pemecahan masalah sangat diperlukan dalam komunikasi konseling untuk membantu klien atau konseli dalam memecahkan masalah-masalah yang dihadapinya. Komunikasi yang sifatnya memecahkan masalah, maka pihak konselor harus mampu mengembangkan suatu mekanisme komunikasi yang memberikan kesempatan kepada klien menyampaikan pendapat dan sumbangan pikirannya. Berdasarkan dari hasil pengamatan yang dilakukan peneliti, Ada tujuh tahapan yang dilakukan konselor dalam memecahkan masalah, yaitu:

1. Menjajangi masalah, yaitu tahapan dimana melalui dialog antara konselor dan siswa menetapkan masalah yang dihadapi

2. Memahami masalah, yaitu tahap lebih lanjut untuk mempertegas masalah yang sesungguhnya beserta aspek-aspek yang terkait yang terkait seperti latar belakang, alasan, tujuan, sumber-sumber terkait, dan sebagainya

3. Membatasi masalah, yaitu tahapan untuk bersama-sama menetapkan batasbatas masalah baik dari dimensi waktu maupun ruang, serta sumber-sumber daya penunjangnya

4. Menjabarkan alternatif, yaitu konselor dan siswa bersama-sama melakukan “curhat pendapat (brainstorming)" untuk menjabarkan berbagai alternatif kemungkinan pemecahan masalah

5. Mengevaluasi alternatif, yaitu menilai setiap alternatif yang telah dikembangkan dalam tahap 4 di atas, setiap alternatif dievaluasi satu persatu dilihat dari kekuatan, kelemahan, peluang, sumber daya dan prioritasnya 
6. Memilih alternatif terbaik, yaitu menetapkan alternatif yang dipandang paling tepat berdasarkan evaluasi dalam langkah 5

7. Menerapkan alternatif, yaitu tahapan melaksanakan alternatif yang dipandang paling baik dalam bentuk tindakan nyata.

Berdasarkan dari hasil pengamatan yang peneliti lakukan banyak pemahaman yang terlahir dari proses tersebut. Konselor pada umumnya melakukan konseling yang menerapkan beberapa tahapan untuk mencapai keberhasilan konseling. Pelaksanaan konseling berjalan sesuai dengan apa yang diharapkan konselor dan konseli, hal tersebut dapat terjadi dikarenakan guru BK SMA Negeri 3 Parepare memiliki pemahaman di bidangnya selaku konselor di sekolah.

Secara pengaplikasian konseling yang dilakukan guru BK SMA Negeri 3 Parepare selaku konselor melakukan beberapa tahapan konseling yang dibuktikan dari beberapa hasil penetilitan di atas. Komunikasi yang terbangun berdasarkan tahapan tersebut dapat dilihat pada tabel di bawah ini;

Tabel Komunikasi yang terbangun berdasarkan tahapan komunikasi efektif yang dilakukan konselor SMA Negeri3 Parepare

\begin{tabular}{|c|c|c|}
\hline No & Tahapan Komunikasi Efektif & Keterampilan Konselor \\
\hline 1 & Fact finding & $\begin{array}{l}\text { - Pengamatan dan penilaian terhadap } \\
\text { perkembangan situasi yang terjadi di lingkungan } \\
\text { siswa di sekolah } \\
\text { - Mengumpulkan data terkait permasalahan yang } \\
\text { terjadi } \\
\text { - Menanalisis permasalahan yang terjadi } \\
\text { berdasarkan dari beberapa sumber informasi }\end{array}$ \\
\hline 2 & Planning & $\begin{array}{ll}\text { - } & \text { Memiliki keterampilan komunikasi yang } \\
& \text { memumpuni } \\
\text { - } & \text { Mengenal siswa secara kepribadian } \\
\text { - } & \text { Mengetahui dan memahami pokok } \\
& \text { permasalahan yang akan dihadapi }\end{array}$ \\
\hline
\end{tabular}




\begin{tabular}{|l|l|l|}
\hline 3 & Communicating & - Attending \\
& & - Empati \\
& & - Bertanya \\
& & - Merangkumkan \\
& & - Bersifat Jujur dan terbuka \\
\hline 4 & Evaluation & - Menerapkan alternatif \\
& & - Memilih alternatif terbaik \\
& & - Mengevaluasi alternatif \\
& & - Menjabarkan alternatif \\
\hline
\end{tabular}

\section{Efektivitas Komunikasi Koselor di SMA Negeri 3 Parepare}

Pada dasarnya untuk mendidik dan mengasuh anak-anak remaja pendidik diharapkan lebih berperan melalui komunikasi secara pribadi dengan anak remaja yang bersangkutan. Karena dengan memahami sifat dan karakter remaja yang bersangkutan akan lebih mempermudah dan memperlancar komunikasi dengan mereka. Senada dengan pembahasan tersebut guru BK SMA Negeri 3 Parepare menjelaskan:

Sangat jelas bahwa memahami kepribadian peserta didik harus diketahui atau dipahami. Hal tersebut dikarenakan mampu membantu kami selaku konselor dalam menentukan sikap yang semestinya kami lakukan pada saat pelaksanaan konseling.

Menyimak dari pelaksanaan konseling yang dilakukan guru BK SMA Negeri 3 Parepare selaku konselor, maka peneliti menarik kesimpulan pada tabel di bawah ini;

Tabel Hasil Efektifitas Pelaksanaan Konseling di SMA Negeri 3 Parepare

\begin{tabular}{|c|c|c|c|c|}
\hline No & Nama Informan & $\begin{array}{c}\text { Tahapan } \\
\text { keterampilan konselor }\end{array}$ & $\begin{array}{c}\text { Keterbukaan } \\
\text { diri siswa }\end{array}$ & $\begin{array}{c}\text { Tingkatan } \\
\text { keterbukaan }\end{array}$ \\
\hline
\end{tabular}

${ }^{7}$ Hj. Rahmatia M., Guru BK SMA Negeri 3 Parepare, wawancara oleh Penulis di Parepare, 29 Oktober 2017 
Aswar Anas, Efektivitas Keterampilan Komunikasi...

\begin{tabular}{|c|c|c|c|c|}
\hline 1 & Fujiyanti Astuti & $\begin{array}{l}\text { - Attending } \\
\text { - Empati } \\
\text { - Bertanya } \\
\text { - Merangkumkan } \\
\text { - Bersikap jujur }\end{array}$ & $\begin{array}{l}\text { Open / Close } \\
\text { Open / Close } \\
\text { Open / Close } \\
\text { Open / Close } \\
\text { Open / Close }\end{array}$ & Open self \\
\hline 2 & Wais Alkarni & $\begin{array}{l}\text { - Attending } \\
\text { - Bertanya } \\
\text { - Merangkumkan } \\
\text { - Empati } \\
\text { - Bersikap jujur }\end{array}$ & $\begin{array}{l}\text { Open / Close } \\
\text { Open / Close } \\
\text { Open / Close } \\
\text { Open / Close } \\
\text { Open / Close }\end{array}$ & Blind Self \\
\hline 3 & $\begin{array}{l}\text { Muhammad } \\
\text { Ridwan }\end{array}$ & $\begin{array}{l}\text { - Attending } \\
\text { - Empati } \\
\text { - Bertanya } \\
\text { - Merangkumkan } \\
\text { - Bersikap jujur }\end{array}$ & $\begin{array}{l}\text { Open / Close } \\
\text { Open / Close } \\
\text { Open / Close } \\
\text { Open / Close } \\
\text { Open / Close }\end{array}$ & Blind Self \\
\hline
\end{tabular}

Melihat tabel di atas tentunya tidak terlepas dari hasil pelaksanaan konseling yang dilakukan guru BK di SMA Negeri 3 Parepare selaku konselor sekolah. Pelaksanaan konseling dilakukan kepada masing-masing siswa yang telah terdeteksi permasalahannya terlebih dahulu agar mendapatkan konseling oleh konselor. Masing-masing siswa yang mendapatkan konseling menemukan hasil berdasarkan uraian tabel di atas.

Fujiyanti astuti merupakan siswa kelas X (sepuluh) di SMA Negeri 3 Parepare yang mendapatkan konseling dengan kasus nilai akademik yang mengalami penurunan dari tahun sebelumnya, dari hal itu sehingga konselor melaksanakan konseling terhadap siswa tersebut. Secara keterampilan komunikasi yang dilakukan konselor menerapkan keterampilan attending, empati, bertanya, merangkumkan dan bersikap jujur. Keterampilan tersebut menemukan hasil bahwa keterbukaan diri siswa tercapai dalam pelaksanaan konseling yang dilakukan konselor pada seluruh keterampilan yang diterapkannya. Oleh karena itu, hasil yang ditemukan peneliti selanjutnya adalah siswa tersebut berada pada tingkatan open self. Hal tersebut dibuktikan berdasarkan dari tingkatan keterbukaan siswa pada seluruh keterampilan komunikasi yang diterapkan oleh konselor 


\section{Keterbukaan Diri Konseli di SMA Negeri 3 Parepare}

Pembahasan untuk memperkuat efektivitas komunikasi konselor maka peneliti menemukan beberapa point penting dalam penelitian ini, terkait keterbukaan diri siswa selaku konseli di SMA Negeri 3 Parepare. Adapun dari hasil penelitian yang dilakukan dengan cara melakukan wawancara terstruktur mengenai aktifitas konseling yang dilalui oleh siswa selaku konseli di SMA Negeri 3 Parepare.

Melihat dari beberapa hasil wawancara ketiga informan, peneliti dapat menarik benang merah bahwa konseling yang dilakukan di SMA Negeri 3 Parepare sangatlah efektif yang dibuktikan dari beberapa penjelasan hasil wawancara di atas. Kepuasan siswa menjadi salah satu kunci keberhasilan guru BK selaku konselor di sekolah, guna untuk memberikan hal yang terbaik kepada siswa di sekolah. Terkait penjelasan pada pembahasan bab pertama, data yang ditemukan adalah guru BK SMA Negeri 3 Parepare selaku konselor menerapkan komunikasi antara pribadi dalam konseling. Oleh karena itu peneliti menjelaskan operasionalisasi dari efektifitas komunikasi antara pribadi yang teradapat pada lima karakteristik adalah:

1. Keterbukaan, setiap siswa di SMA Negeri 3 Parepare yang memiliki masalah pelajaran ataupun masalah pribadi selalu dituntut untuk bercerita kepada guru, khususnya guru BK SMA Negeri 3 Parepare.

2. Empati, maksudnya seorang guru BK yang baik harus bisa menempatkan posisi dan merasakan keluhan yang sedang dihadapi siswanya.

3. Dukungan, guru di SMA Negeri 3 Parepare terutama guru BK selaku konselor selalu mendukung setiap kegiatan siswa tentunya kegiatan-kegiatan positif.

4. Rasa positif, guru BK di SMA Negeri 3 Prepare memiliki rasa positif terhadap siswa yang bermasalah. Karena mereka berpendapat bahwa setiap siswa dapat berubah ketika mereka dapat bimbingan yang baik.

5. Kesamaan, guru BK memiliki kesamaan terhadap siswa. Misalnya guru menginginkan siswanya naik kelas dan lulus dengan nilai yang baik begitu juga 
dengan siswa tersebut. Berarti guru dan siswa memiliki kesamaan, begitu pula dengan guru BK di SMA Negeri 3 Parepare.

\section{Model Komunikasi Efektif Konselor Terhadap Keterbukaan Diri Siswa di SMA Negeri 3 Parepare}

Hasil penelitian terkait pengamatan yang dilakukan peneliti didapatkan bahwa konselor pada umumnya melakukan proses konseling yang menerapkan beberapa tahapan untuk mencapai keberhasilan konseling. Pelaksanaan konseling berjalan sesuai dengan apa yang diharapkan konselor dan konseli, hal tersebut dapat terjadi dikarenakan guru BK SMA Negeri 3 Parepare memiliki pemahaman di bidangnya selaku konselor sekolah. Menurut W.S.Winkel dan M.M. Sri Hastuti;

guru BK adalah seorang tenaga profesional yang memperoleh pendidikan khusus di perguruan tinggi dan mencurahkan seluruh waktunya pada layanan bimbingan dan konseling (full time guidance counselor). Tenaga ini memberikan layanan-layanan bimbingan dan konseling kepada para siswa dan menjadi konsultan bagi staf sekolah dan orang tua.

Pada dasarnya konseling adalah proses yang terjadi dalam hubungan tatap muka antara seorang individu yang terganggu oleh masalah-masalah yang tidak dapat diselesaikan sendiri sehingga harus dibantu oleh seorang pekerja profesional, yaitu orang-orang yang terlatih dan berpengalaman membantu orang lain mencapai pemecahan terhadap berbagai jenis kesulitan pribadi. ${ }^{9}$

Konseling juga diharuskan mengedapankan tahapan konseling yang terbilang efektif sehingga mampu mencapai keberhasilan konseling. Seejalan dengan hal tersebut, komunikasi yang efektif menurut Cutlip dan Center, komunikasi yang efektif harus dilaksanakan dengan melalui empat tahap yaitu:

1. Fact finding : Untuk berbicara perlu dicari fakta dan tentang komunikan berkenaan dengan keinginan dan komposisinya.

\footnotetext{
${ }^{8}$ W.S. Wingkel dan M.M. Sri Hastuti, Bimbingan dan Konseling di Institusi pendidikan, (Yogyakarta: Media Abadi, 2012), h. 184

${ }^{9}$ Soeparman, Bimbingan dan Konseling Pola 17, (Yogyakarta: Ucy Press, 2003), h. 16-17
} 
2. Planning : rencana tentang apa yang akan dikemukakan dan bagaimana mengemukakannya berdasarkan fakta dan data yang diperoleh

3. Communicating : berkomunikasi berdasarkan planning yang telah disusun

4. Evaluation: Penelitian dan analisis untuk melihat bagaimana hasil komunikasi tersebut. $^{10}$

Pelaksanaan konseling tentunya harus dilakukan secara benar dengan mengedepankan prinsip profesional. Bentuk profesional ditunjukkan berdasarkan dari kemampuan para konselor dalam mengelola dan melaksanakan proses konseling agar perubahan yang dilakukan konseli dapat berjalan dengan sewajarnya. Hasil penelitian ini menunjukkan bahwa dari beberapa informan terkait pelaksanaan konseling mengatakan bahwa konselor lebih awal memiliki tuntutan untuk memiliki keterampilan-keterampilan komunikasi agar mampu menunjang terlaksananya konseling. Selain daripada itu penentuan model komunikasi yang digunakan konselor tentunya menyesuaikan terhadap pemahaman awal konselor terhadap situasi konseli.

Mengenai model komunikasi yang diterapkan konselor di SMA Negeri 3 Parepare, adapun hasil pengamatan peneliti terkait tahapan-tahapan keterampilan komunikasi konselor terhadap keterbukaan diri siswa sebagai berikut:

\section{Penghampiran (Attending)}

Penghampiran atau attending dari beberapa penjelasan yang peneliti pahami dimana prosesnya memperhatikan beberapa hal, yakni; 1) ungkapan salam dan sapaan yang penuh sopan, dengan nada suara yang baik. 2) penampilan diri dengan postur (perawakan) fisik yang meyakinkan. 3) gerakan fisik yang disertai dengan perhatian secara menyeluruh. 4) pengakuan, sentuhan dan kontak fisik yang sederhana dan penuh perhatian, disertai dengan sikap yang menunjukkan bahwa kehadiran kita sebagai suatu yang akan memberikan makna bagi para konseli. 5) memelihara kontak mata secara menyeluruh dan cepat sesuai dengan situasi dan topik bahasan. 6) mengamati dan menyimak dengan penuh perhatian. Sejalan dengan Supriono dan Mulawarman yang mengatakan bahwa

\footnotetext{
${ }^{10}$ Deddy Mulyana, Komunikasi Jenaka, h. 77
} 
attending adalah keterampilan atau teknik yang digunakan konseor untuk memusatkan perhatian kepada klien agar klien merasa dihargai dan terbina suasana yang kondusif sehingga klien bebas mengekspresikan atau mengungkapkan tentang apa saja yang ada dalam pikiran, perasaan ataupun tungkah lakunya.

Melihat data yang ditemukan peneliti maka dapat dikatakan bahwa attending merupakan komunikasi yang menunjukkan konselor memberikan perhatian secara utuh terhadap lawan bicara yang sedang berbicara (klien). Keterampilan attending yaitu keterampilan tampil sebagai pribadi yang utuh dan memberikan perhatian penuh kepada klien sebagaimana adanya, agar klien dapat mengembangkan diri, mengeksplorasi dirinya dengan bebas.

\section{Empati}

Berdasarkan hasil pengamatan peneliti pada konseling yang dilakukan guru BK SMA Negeri Parepare selaku konselor menunjukkan bahwa empati kerapkali muncul dalam konseling, pada dasarnya hal tersebut dimulai pada saat konselor mengetahui latarbelakang konseli. Empati yang muncul dikarenakan adanya saling pengertian dan pemahaman terhadap situasi konseli. Pembahasan ini memberikan pemahaman kepada peneliti bahwa konseling dalam tahapannya harus menghadirkan proses saling menerima satu sama lain agar keberhasilan konseling yang dilakukan dapat tercapai. Pembahasan ini sejalan penjelasan D. Goleman yang mengatakan:

Empati merupakan kemampuan merasakan emosi orang lain baik secara fisiologis maupun mental yang terbangun pada berbagai keadaan batin orang lain. Perubahan biologis ini akan muncul ketika individu berempati dengan orang lain. Prinsip umumnya, semakin sama keadaan fisiologis dua orang pada momen tertentu, ${ }_{12}$ semakin mudah pula mereka bisa merasakan perasaannya satu sama lain.

Selain daripada itu, komunikasi dan bahasa sangat mempengaruhi seseorang dalam mengungkapkan dan menerima empati. Hal ini terbukti dalam penyampaian atau penerimaan bahasa yang disampaikan dan diterima olehnya.

\footnotetext{
${ }^{11}$ Supriono dan Mulawarman, Keterampilan Dasar Konseling, (Semarang: Jurusan Bimbingan Konseling FIP UNNES, 2006) h. 19

${ }^{12}$ D. Goleman, Kecerdasan Emosi Untuk Mencapai Puncak Prestasi, (Journal Of Personality And Social Psychology.Vol 44 No 1), h. 165
} 
Bahasa yang baik akan memunculkan empati yang baik, begitu pula sebaliknya komunikasi dan bahasa yang buruk akan menyebabkan lahirnya empati yang buruk.

\section{Merangkumkan (Summary)}

Tahapan keterampilan ini merupakan proses merangkumkan terkait apa yang telah dinyatakan oleh konseli, sehingga berdasarkan data yang ditemukan peneliti menunjukkan bahwa konselor menunjukkan sikap memberikan perhatian dan menyimak siswa dengan penuh perhatian. Sambil mendengarkan dengan penuh perhatian, konselor membuat catatan terkait point-point inti dari penjelasan siswa selaku konseli. Pada tahapan ini kita kaitkan dengan penjelasan Fauzan dkk yang mengatakan bahwa merangkumkan (summary) yaitu teknik respon oleh konselor dalam memadukan uraian pernyataan konseli menjadi kesatuan atau keutuhan tema/topik dari sesi-sesi konseling. ${ }^{13}$ Pada tahap ini tentunya konselor harus mampu mengambil keputusan terkait metode atau skill komunikasi yang tepat berdasarkan situasi siswa. Sehingga hal tersebut dapat mendukung konseling yang berkelanjutan.

\section{Bertanya}

Temuan data observasi yang dilakukan peneliti tentunya tahapan bertanya harus ada penguasaan materi terkait dari apa yang menjadi pembahasan pada konseling yang sedang berjalan. Pertanyaan yang dilontarkan adalah pertanyaan yang tidak membingungkan siswa, dimana pertanyaan mengarah kepada kasus yang ada dan bersifat kongkrit serta sesuai dengan pembahasan. Ketika konselor mendapatkan jawaban dari siswa selaku konseli, maka konselor harus sesegera mungkin memberikan respon balik terhadap jawaban atas pertanyaan yang diajukan, akan tetapi sikap yang kemudian dilakukan adalah yang baik atau empatik.

\section{Kejujuran}

\footnotetext{
${ }^{13}$ Fauzan, Nur hidayah Lutfi dan M. Ramli, Teknik-teknik untuk Konselor, (Malang: Depdiknas UPT BK, 2008), h. 59
} 
Hasil temuan data peneliti terkait tahapan keterampilan kejujuran tergambarkan melalui repon yang diberikan oleh komunikator terhadap orang lain yang bersifat genunie (asli/jujur) adalah respon dengan cara yang ikhlas dan jujur secara emosional dan secara langsung menyatakan perasaan sendiri.

Pembahasan kejujuran disini memiliki pengertian bahwa seseorang konselor itu diharuskan memiliki konsekuensi atau kesesuaian dalam kualitas diri actual (real-self) dengan penilaian orang lain terhadap dirinya (public self). Sikap jujur ini penting dikarenakan:

1. Sikap keterbukaan konselor dan klien memungkinkan hubungan psikologis yang dekat satu sama lain dalam kegiatan konseling

2. Kejujuran memungkinkan konselor dapat memberikan umpan balik secara objektif terhadap klien. ${ }^{14}$

\section{Efektifitas Komunikasi Konselor di SMA Negeri 3 Parepare}

Selain dari pada pemicu munculnya hal yang mampu memberikan kesulitan kepada konselor dalam mencapai kefektifan komunikasi konseling, maka komunikasi dalam komunikasi konseling juga dapat dikatakan efektif dilihat dari proses penyampaian bimbingan yang terjadi ketika seorang guru menyampaikan materi bimbingannya. Sesuai dengan apa yang peneliti temukan di lokasi penelitian dimana guru BK sebelum melaksanakan bimbingan konseling, terlebih dahulu permasalahan yang dimiliki siswa dan menerapkan beberapa keterampilan komunikasi konseling yang dapat menyesuaikan terhadap situasi dalam pelaksanaan konseling. Sehingga pesan-pesan tersebut akan menimbulkan suatu komunikasi yang baik dan mudah dimengerti oleh siswa.

Hasil yang ditemukan peneliti juga menunjukkan bahwa adanya saling mengerti antara konselor dan konseli akan memberikan pertimbangan kepada konselor dalam konseling untuk menyeleksi tiap kata dan ucapan yang tepat dalam penyampaikan pesannya, agar dapat diterima sesegera mungkin oleh konseli. Sama halnya dengan komunikasi konselor yang terjadi, akan semakin

\footnotetext{
${ }^{14}$ Ismatulafwah.blogspot.co.id/2013/05/bimbingan-konseling-keterampilan-dan.html?m=1 (diakses pada tanggal 28 Desember 2017)
} 
mudah proses pengarahan dalam suatu konseling ketika guru BK selaku konselor memiliki pemahaman awal terhadap siswa yang dihadapi dalam konseling. Tidak heran ketika mendapatkan proses komunikasi dalam konseling yang cukup lama dan mendapatkan hambatan di tengah proses berjalannya konseling, hal itu bisa saja dikarenakan tidak adanya hambatan guru BK selaku konselor terhadap apa yang diinginkan oleh siswa.

\section{Keterbukaan Diri Siswa di SMA Negeri 3 Parepare}

Melihat hasil temuan peneliti pada keterbukaan diri siswa SMA Negeri 3 Parepare secara keseluruhan informan mengatakan mengetahui proses pelaksanaan konseling. Hal yang terjadi di dalamnya adalah proses tanya jawab, dimana konselor bertanya kepada konseli serta konseli menjawab dari apa yang ditanyakan oleh konselor. Tentunya bukan hanya sebatas hal tersebut menjadi dasar untuk dikatakan terbukanya siswa, tapi sejauh mana tingkat kepuasan yang dirasakan siswa setelah melewati konseling.

Tingkat kepuasan siswa di SMA Negeri 3 Parepare setelah melalui proses konseling lebih banyak mengutarakan bahwa mereka merasa puas dikarenakan adanya pengertian dari guru BK selaku konselor dalam menyikapi permasalahan yang dimiliki siswa selaku konseli. Selanjutnya tutur kata dan penggunaan kosa kata yang tepat menjadi pemicu untuk keterbukaan diri siswa dikarenakan siswa merasa nyaman dan aman untuk menjelaskan seluruh permasalahan yang ia miliki.

\section{PENUTUP}

\section{Kesimpulan}

Model komunikasi yang diterapkan oleh guru BK di SMA Negeri 3 Parepare selaku konselor dapat diketahui beradarkan tahapan komunikasi efektif, yakni 1.) fact finding dalam pelaksanaannya konselor melakukan pengamatan dan 
penilaian terhadap perkembangan dan situasi yang terjadi dilingkungan siswa di sekolah, mengumpulkan data terkait permasalahan yang terjadi, dan menganalisis permasalahan yang terjadi berdasarkan dari beberapa sumber informasi. 2) Planning dalam pelaksanaannya konselor memiliki tuntutan awal sebelum melaksanakan konseling dengan memiliki keterampilan komunikasi yang memumpuni, selanjutnya mengenal siswa secara kepribadian, mengetahui dan memahami pokok permasalahan yang akan dihadapi dalam pelaksanaan konseling. 3) Communicating dalam pelaksanaannya dilakukan berdasarkan dari beberapa keterampilan komunikasi konselor yakni; attending, empati, bertanya, merangkumkan dan bersifat jujur dan terbuka, dan yang terakhir 4) Evaluation dilaksanakan dengan menerapkan penerapan alternatif, memilih alternatif terbaik, mengevaluasi alternatif dan menjabarkan alternative.

Penerapan konseling di SMA Negeri 3 Parepare yang dilakukan oleh konselor sangatlah berjalan efektif. Berdasarkan temuan peneliti, berdasarkan pelaksanaan konseling yang dilakukan konselor yang menerapkan beberapa keterampilan komunikasi yang dimiliki, yakni; attending, empati, bertanya, merangkumkan dan kejujuran. siswa di SMA Negeri 3 Parepare selaku konseli dalam proses konseling juga tergolong mencapai tingkat keterbukaan diri. Hal tersebut dibuktikan dari hasil obserbvasi dalam pelaksanaan konseling yang menunjukkan keterbukaan siswa berada pada tingkatan open self dan blind self serta beberapa hasil wawancara yang membahas tentang pemberian kepercayaan dari siswa kepada konselor, mengemukakan pernyataan yang jujur dalam proses konseling, serta kepuasaan konseli yang menacapai perasaan yang legah setelah melalui proses konseling di sekolah.

\section{DAFTAR PUSTAKA}

Alwisol. 2005. Psikologi Kepribadian, Edisi Revisi. Malang: UMM Press

Bahri, Syaiful Djamarah. 2003. Strategi Belajar Mengajar. Jakarta: Rineka cipta

Bimo, Walgito. 2004. Bimbingan dan Konseling di Sekolah. Yogyakarta: Andi Offest 
Bungin, Burhan. 2007. Sosiologi Komunikasi: Teori, Paradigma, dan Diskursus Teknologi di Masyarakat. Cet 2; Jakarta: Kencana Prenada Media Group

Damsar. 2011. Pengantar Sosiologi Pendidikan. Jakarta: Kencana

Departemen Agama RI, Alqur'an dan Terjemahnya. Bandung: CV. Al Hikmah

Departemen Agama RI. 2010. Alqur'an dan Terjemahnya. Cet.X. Diponegoro: CV. Penerjemah Al-Quran.

Erman Amti dan Prayitno. 2004. Dasar-dasar Bimbingan dan Konseling. Jakarta: PT Rineka Cipta

Hanafi, Abdullah. 1984. Memahami Komunikasi Antar Manusia. Surabaya: Usaha Nasional

Nur, Hidayah Fauzan. dan M. Ramli. 2008. Teknik-teknik untuk Konselor. Malang: Depdiknes UPT. BK

Nurdin. 2001. Pengantar Komunikasi Massa. Jakarta: Rajawali Pers

Pemendiknas Nomor 27 tahun 2008 Tentang standar Kualifikasi Akademik dan Kompetensi koselor

Usman. 1998. Bimbingan dan Konseling. Jakarta: Bina Aksara

Warner J. Severin, James W. Tankard, Jr. 2009. Teori Komunikasi Sejarah, Metode, dan Terapan di Dalam Media Massa. Jakarta: PT Kencana Prenada Media Grup Cet: V

Widjaya. 2000. Ilmu Komunikasi Pengantar Studi. Jakarta: PT Rineka Cipta, Cet: II

Wilis, S. 2007. Teori dan Teknik Konseling di Sekolah. Yogyakarta: Rineka Cipta

Wingkel, WS dan Sri Hastuti M.M. 2012. Bimbingan dan Konseling di Institusi Pendidikan. Yogyakarta: Media Abadi 